Sign Systems Studies 30.1, 2002

\title{
Pragmatics and biosemiotics
}

\author{
Alexei A. Sharov \\ Virginia Polytechnic Institute and State University \\ Blacksburg, VA 24061-0319, USA \\ e-mail:sharov@vt.edu
}

\begin{abstract}
Pragmatics, i.e., a system of values (or goals) in agent behavior, marks the boundary between physics and semiotics. Agents are defined as systems that are able to control their behavior in order to increase their values. The freedom of actions in agents is based on the distinction between macrocharacters that describe the state or stage, and micro-characters that are interpreted as memory. Signs are arbitrarily established relations between micro- and macro-characters that are anticipated to be useful for agents. Three kinds of elementary signs (action, perception, and association) have been developed in agents via evolution and learning to support useful and flexible behaviors. The behavior of agents can be explained, predicted, and modified using the optimality principle, according to which agents select those actions that are expected to increase their value. However, agents may select actions based on their own model of the world, which have to be reconstructed in order to predict their behavior. Pragmatics in agents can be induced, learned from individual experience or natural selection, or adopted.
\end{abstract}

\section{Introduction}

Charles Peirce (1955) viewed a sign as a triadic relationship between a sign vehicle, an object, and interpretant, which is a representation of the object. For example, smoke is a sign vehicle, fire is an object, and the idea of fire that appears in the mind of the interpreter after seeing the smoke is the interpretant. The relationship between a sign vehicle and an object is arbitrarily chosen, i.e. it does not follow from their physical properties or interactions. A sign vehicle may resemble an object (i.e., an icon) but this resemblance is not necessary, it is optional. 
The Peircean triadic scheme of a sign works well for human signs and even for animal signs in zoosemiotics (Sebeok 1972). Animals have brains and obviously can interpret simple signs similar to humans. But brain is not the only organ that can interpret signs. Sign communication can be found in plants, cells, and even molecules (Uexküll 1982, Sharov 1992). These are non-mental signs, and they are of main interest for biosemiotics, because biosemiotics attempts to understand the origin of signs and their evolution towards mental signs. The idea of non-mental interpretation of signs can be found in the writings of Peirce (1955). But only recently after advances in molecular biology it became clear how vast, complex, and meaningful is the information coded in a DNA. We looked for alien intelligence on other planets, but it appears that a kind of alien intelligence exists in our own bodies. It uses the genetic language for communication, which we mostly do not understand. Thus, the thesis of Dawkins (1986) that there are no creative and intelligent agents in nature besides humans may be wrong.

The major problem with non-mental signs is to determine the boundary between sign interpretation and other interactions of objects (i.e., the boundary between semiotics and physics). Several answers have been proposed.

1. According to a pan-semiotic approach, any physical interaction is semiotic. For example, according to Deely (1992), a bone of a fossil animal is a sign vehicle that points to the original animal, and the rock formation in which the bone was fossilized is the interpreter. There is no doubt that any physical interaction can be used by human interpreters to determine past events, but the claim that rocks themselves are interpreters seems questionable.

2. According to a biological approach, a particular class of living systems is capable of interpretation. For example, Sebeok (1972) considered animals as interpreters of signs. Uexküll (1982) and Hoffmeyer (1996) considered living cells as minimal interpreters. According to Hoffmeyer (1996), neither viruses nor genes are interpreters; they only carry information that becomes interpreted by living cells. The first problem with this biological approach is that artificial non-cellular interpreters are not considered. But robots can perceive signals from the outer world and modify their actions accordingly in the same way as animals do. Second, evolutionary systems (evolving lineages) do not fit to Hoffmeyer's biological definition of an inter- 
preter. I agree with Hoffmeyer that a single virus does not interpret anything, but a population of viruses is capable of perception (via natural selection) and interpretation (Sharov 1998). In the same way, a population of genes can be viewed as an interpreter, which follows from the "selfish gene" idea of Richard Dawkins (1976).

3. According to a system theory approach, interpretation is performed by self-reproducing systems. I have been supporting this approach (Sharov 1992, 2000) and tried to overcome several problems associated with it. The first problem is that some systems do not reproduce but are definitely capable of sign interpretation. For example, a mule can interpret signals at the organism, cellular, and molecular levels. Robots can interpret primitive signals also. The second problem is that primitive self-reproducing systems (e.g., patterns in cellular automata) are not agents because they do not control their actions. And, as we will see below, only agents can use signs.

4. According to a pragmatic approach presented in this paper, the necessary attribute of a sign is its anticipated usefulness for some agent. Pragmatics, which deals with usefulness, values, and goals, is definitely outside of the domain of Newtonian physics. The success of the Newtonian physics is largely due to the idea that dynamics can be separated from pragmatics. For example, the trajectory of a falling rock does not depend on the goals of a person who threw it. But physics is not sufficient for solving problems related to economy, evolutionary biology, artificial intelligence, and biosemiotics, where the pragmatic aspect of agent behavior is very important. I believe that pragmatic/semiotic methods will be useful in these areas.

\section{Agents}

I suggest to replace the notion of interpreter in semiotics by the notion of agent. The term "interpreter" is anthropomorphic and does not imply any active feedback to the world, whereas the term "agent" refers to active interaction with the world and can be applied to a wide variety of systems: organisms, lineages, robots, and even computer programs. I define agents as systems that are able to control their behavior in order to increase their values or achieve goals.

Agents cannot function without signs, which are responsible for storing the information on agent preferences, perceiving the environ- 
ment, and controlling the behavior. Sign relationships are set arbitrarily depending on the needs of agents who use them. Arbitrariness (or freedom) in agents can not be distinguished from randomness unless an agent has values or goals. This is the main reason why semiotics should be linked with pragmatics. Notions of probability and randomness work well with passive systems that do not learn from their experience. But only agents, who can control their actions, exhibit arbitrariness. Obviously, the probability theory is too simple to describe agents.

Somebody may argue that the possibility of an agent to perform alternative actions can be detected if we change the environment. Then arbitrariness of actions can be determined without using pragmatics. I think that there is a hidden fault in this logic. A system that performs differently in various environments does not necessary responds actively to the environment. It may happen that the environment simply induces these changes in a system, which remains entirely passive by itself. For example, water takes the shape of a vessel but it does not respond to vessel's shape. In other words it does not select a shape that will fit this particular vessel. We know this from the fact that water fills the vessel without any learning. In contrast, when an agent happens to be in a new environment, it goes through a learning period trying various actions until it finds a satisfactory one.

But how do we distinguish learning from other transition processes? Water does not fill the vessel instantly; instead there is a process of change that ends when the system reaches a stable state. This process can be easily confused with learning. The difference between transition processes and learning is that the system remembers the results of learning and selects the appropriate action faster when exposed to the same environment or situation repeatedly. But water does not fill the vessel faster after it is poured into the same vessel many times.

Agents are autonomous systems because they control their own behavior. But the degree of autonomy, which can be defined as the proportion of behaviors that are learned and controlled, may be different. Some agents (e.g., humans) are highly autonomous, and others (e.g., robots) are only slightly autonomous. But analogous to the Gödel's theorem, it is impossible for a system to be fully autonomous; i.e., it can never control all its behaviors. To control a 
behavior, the system should first develop a representation (formalization) of this behavior, but not all behaviors can be formalized.

Freedom in agents is based on a limited causal determinism, which means that the dynamics of an agent is not fully determined by its state. Also there should be a kind of "memory" that controls agent's behavior but it is not included into the description of state. Thus, all characters of an agent can be separated into two groups (Sharov 1992):

(1) macro-characters that correspond to agent's structure, phenotype, or hardware, and

(2) micro-characters that correspond to agent's memory, genome, or software.

The dynamics of macro-characters is determined by its macro-state except certain unstable points where the trajectory bifurcates, and the direction can be affected by micro-characters. The idea of the role of bifurcations in the dynamics of living organisms goes back to Waddington (1968). If we do not distinguish between macro- and microcharacters, then there would be no control of actions, no freedom, and hence no agents.

\section{Signs}

I consider signs as relations between micro- and macro-characters that are anticipated to be useful for agents. Peirce did not distinguish between micro- and macro-characters in his theory of signs; thus, it may be difficult to compare his definition of a sign with mine. But some similarity can be found. According to my definition, a sign is triadic because it is not just a relation between a micro- and macrocharacters, but a relation that is anticipated to be useful for an agent. Thus an agent can be viewed as an object for the sign relation. At a closer look, living activities of an agent can be classified into various functions, and these functions are often focused on specific objects (e.g., parts of the body, food items, enemies, etc.). Then, sign relations can be associated with particular functions and objects rather than with an abstract usefulness for the whole agent.

Elementary signs can be classified into three categories (Fig. 1):

(1) Action sign is a relationship between a micro-character and an action (function) that changes macro-characters. For example, a 
gene is a micro-character that is responsible for some metabolic function.

(2) Perception sign is a relationship between a macro-character of an agent or state of the environment and a micro-character. For example mammals can measure the concentration of $\mathrm{CO}_{2}$ in their blood.

(3) Association sign is a relationship between two or more microcharacters. For example, perception of a signal can be associated with a specific action sign.

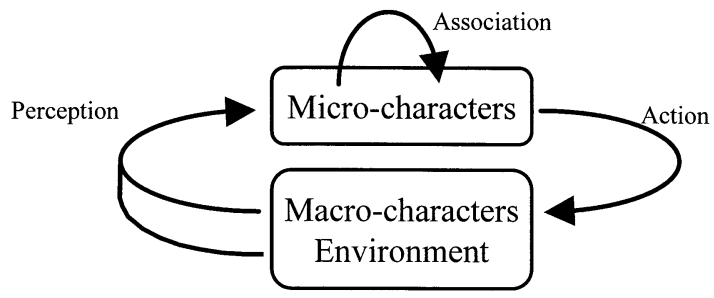

Figure 1. Action, perception, and association signs in agents.

In this classification I combined the perception of the environment with the perception of agent's state because simple agents do not recognize the existence of the environment. They treat the environment as a part of their own macro-state. For example, an agent may have a thermoreceptor that measures body temperature, but it may be unaware that body temperature is the same as in the environment. Advanced agents distinguish environmental characters as those that are not affected by their activity. Hence, they can recognize which receptors measure the internal state, and which measure the environment.

Peircean signs can be represented by a combination of elementary signs (Fig. 2). In this example, the visual perception of a smoke is the immediate interpretant, which activates the smoke concept (the second-level interpretant). At this point, the object is recognized as smoke and the fire concept (the third-level interpretant) is activated via the association sign. Finally, the fire concept may materialize in fire-related actions. 


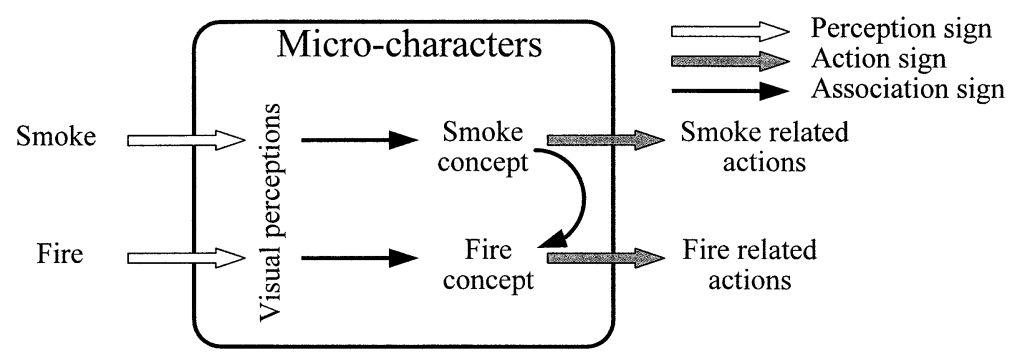

Figure 2. A combination of elementary signs that form a Peircean sign.

The arbitrariness of actions and perceptions in living organisms exists both at the individual and evolutionary levels. Animals have control over their immediate perceptions, e.g., changing their field of view. But they cannot increase the sensitivity of their sense organs, or change the spectrum of perceived signals. However, sense organs may change in the evolutionary time scale.

Evolving lineages should be viewed as agents in whom microcharacters are preserved from one generation to another via inheritance. Besides fast actions and perceptions at the level of individuals, lineages have a long-term "perception" in the form of natural selection (Sharov 2000). Perception in individual organisms is based on a selective excitation of receptors. When some photoreceptors in the eye become excited, we see an image that gives us information about the environment. In the same way, selective survival of organisms provides information for the lineage on what genomes are most successful in a given environment. Natural selection is often erroneously compared with a passive sieve. This is a misleading metaphor because living systems develop mechanisms that control their variability, avoid death, and ensure reliable reproduction. The evolution of adaptability (Conrad 1983) is not compatible with the sieve metaphor. However, natural selection is a very ineffective way of collecting information. Each bit of information literally cost lives. Individual perception is a mechanism that substitutes natural selection and makes life more efficient. 


\section{Values}

If a system prefers some actions over others then preferred actions have higher values for this system than those that are rejected do. In other words, the behavior of an agent is consistent with its values (or goals). Due to this consistency we are able to recognize agents and to distinguish them from mere stochastic systems.

Value has a circular definition: it is proportional to the rate of value generation. Circular definitions are not necessary corrupt because mathematics can easily handle equation where the same variable is present both in the left and right side. If a state has a high value then it will generate even more additional value in the future compared with states that have a lower value. In Fig 3A, values are consistent with dynamics because all preferred transitions increase the value. In Fig 3B, values are not consistent with dynamics because state $b$ has a smaller value than state $d$, but in the future it generates more value than state $d$.

Because agents have control over their transitions, their values depend on their knowledge. In Fig 3C, an agent $a$ can change into $d$ but it does not know a transition to state $b$. If it learns how to reach the state $b$, then it will prefer the transition to $b$ over the transition do $d$; and its value will increase due to this knowledge. Values are consistent with behaviors that are selected by the system, rather than with objective dynamics based on laws of physics. Thus, knowledge represented by a system of signs may increase the value of the system.

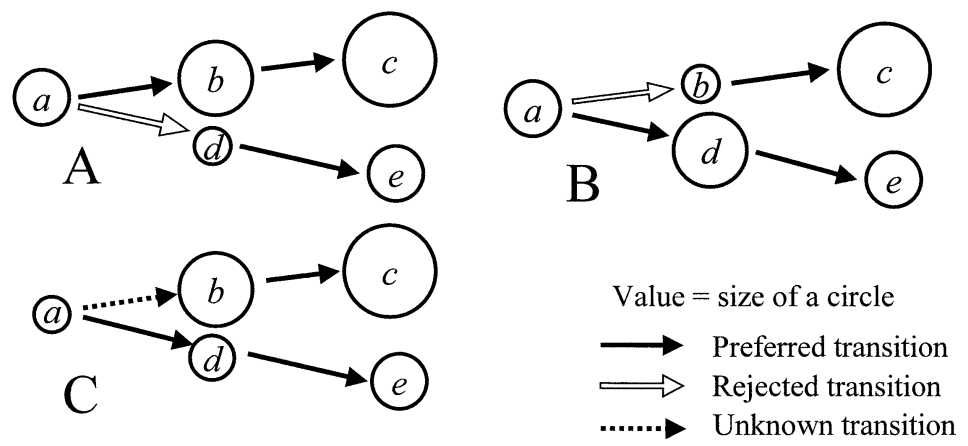

Figure 3. Consistency of agent values with preferred transitions between states. 
In an isolated system, values of individual components (stages or states) can be estimated using linear algebra. For example, if the dynamics of an age-structured population is described by a liner differential or difference equation with matrix $\mathbf{A}$, then reproductive values of organisms at each age are equal to the components of the left eigenvector of matrix A (Pielou 1974). This method for value estimation works both in economy and in biology. Fisher (1930) was the first to discover the similarity of these two disciplines that are both focused on pragmatics. An organism is like a business project; it requires an initial investment in the form of an egg, parental care could be an additional investment. Then an organism produces progeny, which is equivalent to the profit from a business project. The value of a business project or an organism is the left eigenvalue of the matrix for system dynamics and estimated using the same equation. In economy it is called "present value" and in biology it is called "reproductive value".

The calculation of values may become more complicated in nonlinear systems. If may require linearization at an appropriate time scale, at which the dynamics becomes more or less stationary. In cyclic populations, some behaviors may be beneficial at low population density and harmful at high density. The true value of each behavior can be estimated only by averaging its outcomes over large time periods

\section{Optimality principle}

Values can be used to explain, predict, and modify agent's behavior based on a set of assumptions called "optimality principle". The most simple formulation of this principle is that an agent selects a behavior that generates maximum value. The role of signs is to help agents to select best actions. Thus, the optimality principle is based on semiotics rather than physics.

Consider a question "why a caterpillar turns into a butterfly?" Evolutionary biologists will answer that a caterpillar turns into a butterfly because a butterfly can lay eggs. But this answer is not satisfactory because it only leads to another question: "why butterflies have to lay eggs?" The correct answer is that a caterpillar turns into a butterfly because the reproductive value of a butterfly is higher that 
the reproductive value of a caterpillar. Developing into a butterfly is a way to increase organism's value. Of course, an individual caterpillar does not have many other options rather than to develop into a butterfly. The only other option would be to die. But the lineage of butterflies may have more freedom: it may generate a mutation so that the caterpillar will turn into a different kind of butterfly. It may also control the rates of development, diapause, and other life-cycle characteristics.

Now let us consider another question: "why butterflies lay eggs?" The reproductive value of a butterfly may decrease after laying an egg. Then, why to produce it? The answer is that we need to count the sum of values of all products, i.e., the value of the butterfly plus the value of an egg. If this sum is greater than the value of the butterfly before egg laying, then the production of an egg is justified.

The optimality principle can be formulated in a variety of ways from "hard" to "soft". The hard optimality principle assumes that systems select their best action within given constraints based on the true model of the world that coincides with our (human) model of the world. Thus, the behavior that is optimal from our point of view is really optimal for the agent. The hard optimality principle is easy to apply and it works fine in many cases. However, its assumptions are too strong and may be not satisfied in many systems. The soft optimality principle assumes that a system selects an acceptable action based on its own local understanding of the world and its control abilities. We (researchers) also have a limited and local understanding of the world. And it may happen that the agent, whose behavior we study, understands the situation better than we do. The soft optimality principle is definitely more universal, but also it is more difficult to use because it requires the reconstruction of agent's model of the world. This can be done if we read the optimality principle backwards: we observe agent's behavior and then predict a world model in which this behavior is optimal.

Agents interpret signs because they anticipate to increase their value. By anticipation I do not necessary mean an emotional state of an organism, but rather an evolutionary-confirmed association between a sign and additional value obtained from its interpretation. For example, male moths are attracted to the pheromone emitted by a female, and this behavior increases their chances to mate. Thus, the interpretation of pheromone signals increases the reproductive value 
of male moths. Perception signs also increase the reproductive value not via immediate actions, but because the agent may be able to perform additional activities in the future based on obtained knowledge about its environment. Some agents are able to produce signs anticipating to get additional value in the future. Female moth emits pheromone to increase mating chances.

\section{Sources of agent pragmatics}

Agent's system of values (pragmatics) can come from the following three sources (Fig. 4).

1. It can be induced by another system. For example, parents induce inherited behaviors in their offspring. In some cases a nonparent can induce pragmatics. For example, larvae of parasitic wasps can change the hormonal status of their hosts in a way that is beneficial for the parasite. Viruses induce a different behavior in their host cells. Induced behavior in man-made automata fits into this category too.

2. Pragmatics can be learned from experience. There are two levels of learning: simple learning is based on tries and errors, and more effective learning can be done using models. Simple natural selection and simple conditioning correspond to the try/error mode of learning. Multilevel selection and conditioning correspond to models of different degree of sophistication.

3. Finally, pragmatics can be adopted from other systems. The difference from induced pragmatics is that here an agent has a choice which system of values to select. In other words, pragmatics is accepted consciously. For example, if a person becomes a member of some organization he/she often accepts the pragmatics of this organization. 


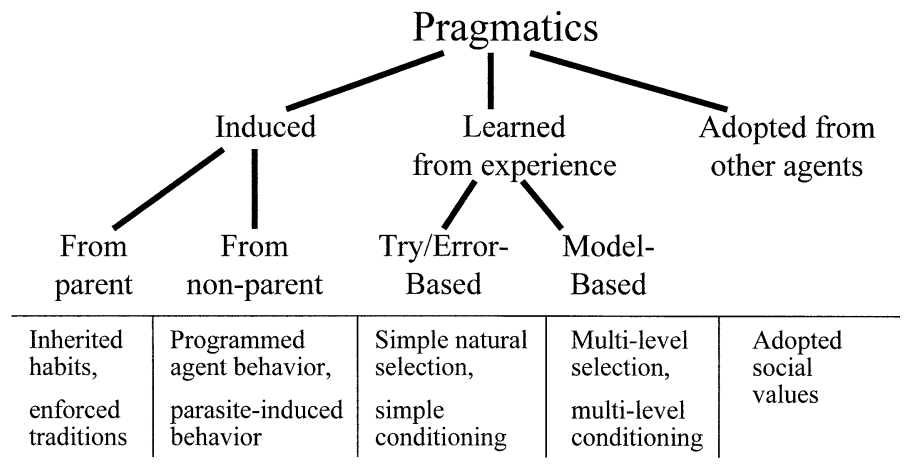

Figure 4. Sources of pragmatics in agents.

Pragmatics of any system may be partially induced, partially learned, and partially adopted. These portions do not necessary generate a consistent system of values. If values do not match, then the system may represent different agents at the same time. For example, an animal has its own pragmatics learned during its lifetime; but it also behaves according to the values of the lineage tested over long evolutionary times.

\section{References}

Conrad, Michael 1983. Adaptability:The Significance of Variability from Molecule to Ecosystem. New York: Plenum Press.

Dawkins, Richard 1976. The Selfish Gene. New York: Oxford University Press.

- 1986. The Blind Watchmaker. Harlow: Longman Scientific \& Technical.

Deely, John N. 1992. Semiotics and biosemiotics: Are sign-science and lifescience coextensive? In: Sebeok, Thomas A.; Umiker-Sebeok, Jean (eds.), Biosemiotics: The Semiotic Web 1991. Berlin: Mouton de Gruyter, 47-75.

Fisher, Ronald A. 1930. The Genetical Theory of Natural Selection. Oxford: Clarendon Press.

Hoffmeyer, Jesper 1996. Signs of Meaning in the Universe. Bloomington: Indiana University Press.

Peirce, Charles S. 1955. Philosophical Writings of Peirce. Buchler, Justus (ed.). New York: Dover Publications.

Pielou, Evelyn C. 1974. Population and Community Ecology: Principles and Methods. New York: Gordon and Breach Science Publisher. 
Sebeok, Thomas A. 1972. Perspectives in Zoosemiotics. The Hague: Mouton de Gruyter.

Sharov, Alexei A. 1992. Biosemiotics: A functional-evolutionary approach to the analysis of the sense of information. In: Sebeok, Thomas A.; Umiker-Sebeok, Jean (eds.). Biosemiotics: The Semiotic Web 1991, Berlin: Mouton de Gruyter, 345-373.

- 1998. From cybernetics to semiotics in biology. Semiotica 120(3/4): 403-419.

- 2000. Semiosis in self-producing systems. In: Dubois, Daniel M. (ed.), Computing Anticipatory Systems: CASYS'99 - Third International Conference, Liege, Belgium, 9-14 August 1999. (American Institute of Physics Conference Proceedings 517.) Melville: American Institute of Physics, 244-251.

Uexküll, Jakob von 1982. The theory of meaning. Semiotica 42(1): 25-82.

Waddington, Conrad H. 1968. The basic ideas of biology. In: Waddington, Conrad H. (ed.), Towards a Theoretical Biology. I. Prolegomena. Edinburgh: Edinburgh Univ. Press, 1-41.

\section{Прагматика и биосемиотика}

Прагматика, т.е. система ценностей (или целей), которая проявляется в поведении действующего [agent], проводит границу между физикой и семиотикой. Агенты дефинируются как системы, способные контролировать свое поведение с целью увеличения собственной ценности. Свобода действия агентов основывается на различии между макровсойствами, характеризующими положение или уровень и микросвойствами, которые интерпретируются как память. Знаки - арбитрарно установленные связи между микро- и макросвойствами, причем предполагается их полезность для агента. В ходе эволюции и обучения у агентов выработались элементарные знаки трех типов (действие, ощушение и ассоциация) для обеспечения полезных и гибких способов поведения. Поведение агентов можно объяснить, предсказать и модифицировать в соответствии с приципом оптимальности, согласно которому агенты выбирают такие действия, которые предположительно увеличивают их ценность. Но агенты могут выбирать действия и в соответствии с собственной моделью мира, которую нужно смоделировать для предсказания их поведения. Прагматика агентов может быть индуцирована, выучена в ходе индивидуального опыта или естественного отбора или заимствована. 


\section{Pragmaatika ja biosemiootika}

Pragmaatika, s.t väärtuste (või eesmärkide) süsteem, mis avaldub toimija [agent] käitumises, tähistab piiri füüsika ja semiootika vahel. Toimijad defineeritakse kui süsteemid, mis on võimelised kontrollima oma käitumist enese väärtuse suurendamise eesmärgil. Toimijate tegevusvabadus põhineb eristusel ühelt poolt olukorda või taset iseloomustavate makro-omaduste ja teisalt mäluna tõlgendatavate mikro-omaduste vahel. Märgid on arbitraarselt loodud suhted mikro- ja makro-omaduste vahel, millest eeldatakse, et need on toimijatele kasulikud. Evolutsiooni ja õppimise käigus on toimijatel arenenud kolme liiki (tegevus, taju ja seostamine) elementaarsed märgid kasulike ja paindlike käitumisviiside tagamiseks. Toimijate käitumist on võimalik seletada, ennustada ja modifitseerida vastavalt optimaalsuse printsiibile, mille järgi toimijad valivad selliseid tegevusi, mis eeldatavasti suurendavad nende väärtust. Ent toimijad võivad valida tegevusi vastavalt oma maailmamudelile, mis tuleb nende käitumise ennustamiseks rekonstrueerida. Toimijate pragmaatika võib olla indutseeritud, õpitud individuaalse kogemuse või loodusliku valiku käigus, või üle võetud. 